\title{
Ending isolation? Leprosy, welfare and Indigenous Australians 1950-86
}

\section{Charmaine Robson}

When Derby leprosarium in north-west Western Australia closed its doors in 1986, it finally ended the century-old Australian public health policy of detaining people with leprosy at special sites of isolation. As with its counterparts in the Northern Territory and northern Queensland - East Arm and Fantome Island, which closed in 1982 and 1973 respectively - the vast majority of patients were Indigenous Australians, mostly from remote parts of the continent. Under state and territory health legislation, these people could be compelled to enter the leprosarium and submit to treatment for as long as departmental authorities deemed. Members of other races were also susceptible to leprosy, but, from the late 1950s, most were treated for short periods in hospitals or at home, rather than in a leprosarium.

This article investigates why leprosarium isolation continued for so long, particularly for Indigenous people. This group was the most profoundly disadvantaged by the leprosy isolation policy of the twentieth century, being the most numerous and incurring the particular cultural and social impacts of leprosarium institutionalisation, both as patients and as members of communities. The toll of leprosy isolation was heavy for everyone affected, but policies concerning European Australians will be drawn on for comparative purposes only, here; their histories remain to be told more fully elsewhere.

It is difficult to explain the survival of rigid isolation measures into the late twentieth century, long after effective treatment for leprosy became available in Australia in 1948. From its instigation in Australia in the late nineteenth century until this time, compulsory isolation was more easily justified on the grounds that leprosy was a much feared, contagious disease for which there was no reliable medical treatment. In the interwar period, however, as historians 
have argued, leprologists were divided on whether these considerations outweighed the inhumanity of the practice. Some also believed the policy was counterproductive to the eradication of the disease since the prospect of exile drove sufferers into hiding where the disease could be spread unabated. Others, including doctors who influenced Australian health policy, were unconvinced and staunchly supported stringent isolation practices. ${ }^{1}$ Yet this once impassioned and public debate hardly surfaced following the successful introduction of leprosy drug therapy - a therapy that, by drastically reducing a patient's infectivity, appeared to eliminate any argument for leprosarium isolation.

International studies indicate that in some other countries advances in drug therapy were slow to modify leprosy control policies. Michelle Moran argues that in the United States this development led to increased testing and research, and thus 'initially intensified institutional control over patients'. ${ }^{2}$ In the United States and Japan, medical developments had little effect on policy. Reform occurred gradually, with social and economic factors driving changes in law and the closure of the leprosaria. ${ }^{3}$ Angela Ki Che Leung's argument that isolation measures in China intensified in the 1950s as part of the Great Leap Forward is a reminder of the persistent historical connections between the national political landscape and leprosy management. ${ }^{4}$ These findings suggest the need for caution in linking policy reform to scientific developments without consideration of the influence of wider social or political issues.

The divergence of Australian leprosy control policy along the lines of race from 1950 deserves particular attention. Historians have commented on this emergence of a more overt racially inequitable policy, but have not subjected it to sustained analysis, nor questioned why this continued for a further three decades. For Alison Bashford, it was not so much a change, as an intensification of the existing racial anomalies enabled through decisions 'constantly made on the ground'. ${ }^{5}$ This bifurcation of policy coexisted with commitments by governments in the 1950s to iron out racial inequities in the healthcare and welfare sectors under the policy of assimilation. The Welfare Ordinance 1953 (NT), the policy's main instrument in the Northern Territory, emphasised the 'physical well being' and 'social, economic and political advancement' of Indigenous people so they could 'take their place as members of the community of the Commonwealth'. ${ }^{6}$ As Anna Haebich has argued, assimilation implied the incorporation of Indigenous healthcare into mainstream medical

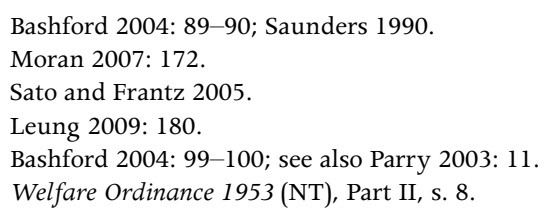


services. ${ }^{7}$ Indeed, reforms of racially exclusionary welfare policies, such as the Commonwealth social security system, suggested the state's growing recognition of the rights and needs of aged and disabled Indigenous people, and a general shift towards equity in social policy. Yet it was in this period that divisions deepened between leprosy policy for Indigenous and other Australians.

A second task of this article is to identify divisions remaining embedded in healthcare and welfare systems of the 1950s and 1960s to determine their scope for assisting the recovery and deinstitutionalisation of leprosy patients, many of whom had developed physical impairments. From the 1940s, the Commonwealth Government's strengthened commitment to the rehabilitation and social reassimilation of groups such as returned soldiers, tuberculosis sufferers and invalid pensioners resulted in a raft of welfare provisions including cash benefits, health services, and retraining programs. ${ }^{8}$ Historian Stuart Macintyre argues that these welfare measures looked to 'strengthening the social fabric' by maximising employment opportunities and protecting against hardship. ${ }^{9}$

This article draws on Indigenous disability studies. Helen Meekosha argues that the concept of disability in Indigenous people is inextricable from the disabling effects of colonisation on all Indigenous Australians, with or without physical or mental impairment. ${ }^{10}$ Imported diseases, the Western diet, dislocation, dispossession of land, and the removal of children left a legacy of chronic health problems in the Indigenous population. Included in these 'state-created impairments', to use David Hollinsworth's term, were the 'racist representations of Indigenous people and their consequent treatment', through, for example, practices of exclusion, intense surveillance and/or institutionalisation. ${ }^{11}$

This study aims to contribute to an understanding of the [post]colonial 'disabling' of Indigenous people. Leprosy itself, introduced to the Indigenous race as a result of European settler society incursions in the late nineteenth century, was a tragic consequence of colonisation, as manifested in the deaths, maiming and serious illness it caused. Governments compounded this problem, enforcing policies and laws that prescribed leprosarium isolation and targeted Indigenous people under revised policies from 1950. Taking up Hollinsworth's perspective, I will argue here that these policies endured - when medical science and social change determined they should cease - in part because of the persistence of a racialised medical and bureaucratic discourse in the 1950s and early 1960s, framing Indigenous patients as unfit for living outside institutional oversight. In addition, I will take Meekosha's argument further, showing that

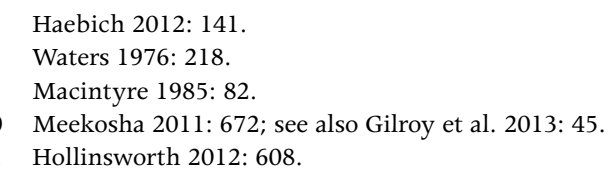


the colonial legacy of inadequate living conditions, diet, healthcare and welfare services typifying the lives of many remotely based Indigenous people was used by health administrators as justification for extending leprosarium isolation and forced relocation of those with leprosy.

Since at least the early twentieth century, doctors have understood leprosy to be a mildly contagious bacterial disease caused by the organism Mycobacterium leprae. The precise means of transmission was unclear (and remains so), but was thought to occur either through the respiratory route or via skin contact. Essentially, the disease involves the nerves and skin; while its effect on some individuals is mild, it can induce serious, sometimes fatal conditions. Others survive for decades and, without treatment, may incur debilitating conditions such as deformity of the feet and hands, blindness and ulceration. By the interwar period, doctors distinguished between the more invasive and infectious form of leprosy and the non-infectious type ('lepromatous' and 'tuberculoid' types respectively). They also knew that the incubation period to be at least five years, so that by the time a person's condition became evident, others may have been infected. Nevertheless, isolating the patient from society was considered the only way of controlling the spread of the disease at a time when the only treatment available, Chaulmoogra oil, had limited value. ${ }^{12}$

Leprosy was first noticed in Australia when a minor, short-lived outbreak occurred in Victoria in the middle of the nineteenth century. In the 1890s, it became endemic in New South Wales, Queensland, the Northern Territory and northern Western Australia, afflicting people of various races. In the same decade it was first found in Indigenous people, mostly in the latter three regions. ${ }^{13}$ In line with public health conventions in the colonies of Great Britain and elsewhere, Australian governments ordered the removal of individuals identified with leprosy and their permanent or long-term detention at remote sites or islands. ${ }^{14}$ Officially, the same fate awaited people of any race, as law and policy made no distinction in this regard. However, from the late 1920s, Indigenous notifications began outnumbering all others, and case-finding expeditions and institutional isolation measures targeting Indigenous people intensified across northern Australia. ${ }^{15}$ Consequently, three new leprosaria were established for Indigenous patients at Channel Island (1931), Derby (1936) and Fantome Island (1940). The first patients admitted to the latter institution had come from Queensland's Peel Island Leprosarium, which thereafter took only European patients. By 1950, 86 per cent of the 587 people in Australian leprosaria were Indigenous. ${ }^{16}$

\footnotetext{
Cumpston 1989 [1928]: 215-17.

3 Cumpston 1989 [1928]: 209.

14 Bashford 2004: 88.

15 Cumpston 1989 [1928]: 209.

16 Commonwealth Bureau of Census and Statistics 1953: 303.
} 


\section{The new therapy}

The breakthrough in therapy for leprosy can be traced to the Carville Leprosarium in the United States where, in 1941, researchers conducted successful trials with the patients using injections of Promin, a member of the sulphone group of drugs. By suppressing replication of the bacteria, this agent caused clinical improvement in patients and inhibited the progress of the disease. ${ }^{17}$ Through the 1940s, further research brought sulphone therapy within the reach of wider populations by yielding safer, cheaper and more convenient derivatives. Leprologists stopped short of hailing sulphone therapy as a cure, as not all patients responded well; rather, they used the term 'arrested' to describe the disease in those no longer displaying clinical and bacteriological signs. ${ }^{18}$ Nevertheless, in 1948, the Fifth International Leprosy Congress in Havana pronounced that the sulphones were the drugs of choice for leprosy. ${ }^{19}$ Their effectiveness was stressed that same year in a study by American researchers, G.H. Faget and Paul Erickson, with dramatic photographic evidence of the healing of severe facial lesions after several years treatment. ${ }^{20}$ Two years later, a senior international research team concluded 'we are ready to agree with others that a new day has dawned in the history of leprosy'. ${ }^{21}$

Medical research continued throughout the 1940s and 1950s in the quest to refine drugs and to treat the many conditions induced by the disease, such as other infections, eye disorders and deformities. By the late 1940s, surgery became available to repair deformities of the hands and feet resulting from nerve damage, thus restoring functions such as grasping tools. ${ }^{22}$ Because the drugs drastically reduced the infectivity of patients, it became increasingly difficult to justify their continued isolation in leper colonies and institutions, and health administrations in some countries began to modify their isolation requirements. In 1948, for example, Carville patients whose disease was still active were allowed to leave the leprosarium if they complied with certain requirements such as regular medical checks. ${ }^{23}$

As scholar Zachary Gussow has argued, the formation of the World Health Organization (WHO) after World War Two and its establishment of the Expert Leprosy Committee in 1952 were integral in fostering changes in attitudes and the treatment of leprosy sufferers around the world in the second half of

17 Faget and Erickson 1948: 452.

18 Sloan et al. 1950: 5.

19 Anon. 1948: 209.

20 Faget and Erickson 1948: 453-54.

21 Sloan et al. 1950: 1.

22 Banerjee 2006: 137. Marion and Hargrave 1965: 36-37.

23 Sato and Frantz 2005; see also discharge of patients in Hawaii in Sloan et al. 1950: 5. 
the twentieth century. ${ }^{24}$ The committee consisted of a group of leprologists and epidemiologists with expertise and experience from around the world. They met regularly, reporting on the status of the disease internationally, and formulating international guidelines on leprosy management. Their targets were the health administrations, voluntary organisations and carers involved with leprosy sufferers globally. As Gussow's study highlights, the committee not only aimed to eradicate the disease, but it also emphatically recommended programs to promote the health and social welfare of leprosy sufferers. ${ }^{25}$

Published in 1953, the committee's first report denounced strict leprosy isolation policies in light of the therapeutic inroads made by sulphone therapy: 'the more effective modern treatment giving better chances of recovery calls for a reconsideration of existing practices regarding compulsory isolation' ${ }^{26}$ Only 'infectious cases needed to be subjected to some form of isolation'.$^{27}$ The committee particularly disapproved of isolation at remote sites or islands, for 'the old idea that leprosy is so infectious that patients must be segregated in a distant place is one to be deprecated'. ${ }^{28}$ It was opposed also because it deterred patients from coming forward for treatment, thus allowing the disease to spread. Further, it was considered detrimental to family relationships and to the financial welfare of patients' dependants. ${ }^{29}$

Other recommendations in the first and the subsequent reports of 1960 and 1966 related to the recovery of patients and their adjustment to life outside the institution. The First Report advised that surgery should be 'given a larger place in all institutions caring for leprosy patients' to reduce deformity. ${ }^{30}$ The Second Report devoted a whole section to the 'Rehabilitation of Disabled Patients', reiterating the need for more surgical programs, as well as occupational therapy and physiotherapy interventions 'so that [the patients] may be able to resume their place in the home, society and industry' ${ }^{31}$ The Third Report turned its attention to financial welfare, stating: 'Governments should provide social assistance to leprosy patients and their families, according to existing facilities, in the same way as it is given to other disabled persons. ${ }^{32}$

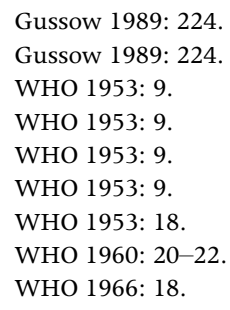




\section{Australian leprosy policy after 1950}

Sulphone therapy became available in Australia in 1947. Because the first supplies came only in injectable form, health authorities believed continual medical oversight was required, and restricted treatment to facilities such as Queensland's Peel Island Leprosarium where a medical officer was in residence. ${ }^{33}$ In 1948, with the availability of orally administered medication, patients at all three Indigenous institutions finally commenced treatment. ${ }^{34}$ The results in Australia reflected the experience overseas that, generally, patients' conditions improved dramatically. ${ }^{35}$ Some patients took longer than others to respond and, indeed, there were several who did not respond at all, or suffered serious physiological reactions. However, developments in drug therapy continued apace during the 1950s and 1960s, with refinements of the sulphones as well as the addition of other agents, including corticosteroids and different antibiotics. Increasingly, drugs helped a wider range of patients in Australia and, for the first time, ameliorated many of the debilitating conditions arising from leprosy, such as ulcers.

By 1950, these positive results, together with changing practices overseas, prompted Australian health authorities to reassess leprosy control policy, in particular, the question of leprosarium isolation. It is important to explain how policy was decided and by whom. Legal provision to detain people with leprosy in specific institutions lay with state and territory government 'leprosy' ordinances, or clauses within health acts. This legislation also granted heads of health departments the power to release people from detention and retain them under surveillance, except the Western Australian act, which was silent on this matter. ${ }^{36}$ The Commonwealth Health Department, however, also wielded considerable authority over leprosy policy: first, with respect to Northern Territory patients through its control of the Territory's health department; and, second, through the National Health and Medical Research Council (NHMRC). This body financed research projects and devised health policy guidelines through expert committees comprised of scientists and specialist doctors. Australian leprosy management was one area under regular discussion by the Committee on Tropical Physiology and Hygiene (CTPH).

\footnotetext{
33 Qld Health and Medical Services Branch (hereafter QHMS) 1947: 7; A.J. Metcalfe, Acting Commonwealth Director-General of Health to J.G. McGlashan, Commonwealth Medical Officer, Northern Territory (hereafter CMO NT), 9 December 1946 in National Archives of Australia (hereafter NAA) A1928, 715/38/1 SECTION 3; J.G. McGlashan, CMO NT to Mr H.I.C. Dent, Promotion Manager, Parke, Davis \& Co, 6 November 1947, NAA A1928, 715/38/1 SECTION 3 .

34 QHMS 1949: 13; Dr Herz, 'Notes' in Davidson 1978: 174; Humphry 1952: 573.

35 Humphry 1952: 573; QHMS 1956: 19 and 1957: 17.

36 Leprosy Ordinance 1928 (NT); Health Act 1911 (WA) s. 273, 'Treatment and Custody of Lepers'; Health Act 1937 (Qld) s. 51, 'Leprosy'.
} 
In 1950, the CTPH reviewed Australian leprosy policy in light of the recent therapeutic advances, concluding: 'The time is not ripe in Australia for abandoning the present prophylactic system.' ${ }^{37}$ This statement was supported with the view that the drugs had not proved to be effective and that isolation was to be maintained in order to provide 'close and constant medical supervision for lengthy periods' ${ }^{38}$ This stance was maintained in the 1958 report, despite the accumulation of further scientific evidence of treatment efficacy, both in Australia and overseas. ${ }^{39}$ That some Australian medical experts remained sceptical about the drug therapy at this time is evident in a warning issued in 1957 by the Commonwealth Health Department in its journal, Health, against 'the over-optimistic interpretations of work published by United States workers at Carville'. ${ }^{40}$

The CTPH reports of the 1950s allowed for the discharge of patients from isolation after a period of treatment as long as certain criteria were satisfied. The committee members thus indicated their limited support for current therapies. Patients must have had two years of steady improvement in their condition, as well as an unbroken series of 12 negative results from monthly bacteriological tests. The reports also listed requirements regarding the conditions and facilities of the patient's intended destination on discharge. In summary, patients had to have access to a medical practitioner for regular reviews and the means to continue their treatment, a fixed address, 'separate accommodation and utensils, an adequate diet and no domiciliary contact with children'. If the patient had a physical disability, nursing and other support 'to preserve him from hardship, starvation or other factors lowering resistance' was required. ${ }^{41}$ The objectives here were the continued surveillance and treatment of discharged patients, and the maintenance of their health and hygiene, so that relapse and subsequent spread of the disease was avoided.

The CTPH reports added another, more explicit, layer of restrictions on Indigenous patients in a section defining the cases warranting isolation. 'Native full bloods' needed only to be 'clinically suggestive' of the disease, regardless of bacteriological results. For 'European patients', however, both bacteriological and clinical evidence were required. Decisions respecting another racial category, 'native mixed bloods', depended on the extent to which the individual's way of life resembled that of a 'full blood' or 'European'. Furthermore, exclusive to the category of 'native full bloods' were 'cases liable to relapse who cannot be

\footnotetext{
NHMRC 1950, 'Leprosy', NAA A1658, 258/1/1 PART 1: 2.

38 NHMRC 1950, 'Leprosy', NAA A1658, 258/1/1 PART 1: 2.

39 NHMRC 1958: 20-26.

40 Commonwealth Department of Health 1957: 21.

41 NHMRC 1950, 'Leprosy', NAA A1658, 258/1/1 PART 1: 3.
} 
kept under satisfactory supervision outside the institution' ${ }^{42}$ A medical source indicates that the term 'liable to relapse' referred to those patients who had the more infectious form of leprosy. ${ }^{43}$

The general discharge criteria imposed long delays and obstacles to release for all patients. However, for Indigenous patients, many of whom came from remote districts with inadequate health services and living conditions, the requirements could be prohibitive. Add to these the specific isolation criteria for Indigenous people, and it is evident that the CTPH recommendations worked against the likelihood of their being released, and in favour of their prompt isolation. Indeed, the CTPH conceded that the implementation of these guidelines 'will necessarily involve discrimination between the races' ${ }^{44}$

Discrimination operated on two different levels. First, there was the kind alluded to in the report, that is, the automatic disqualification of many Indigenous people from acquiring liberty, due to poor home living conditions. The second form of discrimination can be found in the racial discourse informing the committee members' recommendations. The special isolation criteria for Indigenous people imply that these doctors saw them as a quintessentially irresponsible race whose members were safer in a leprosarium than free to manage their own health. This mistrust must have surely run deep to justify such an extreme measure, merely on suspicion of the presence of the disease, or on its chance of recurrence. More insights into this perspective may be garnered from a 1952 journal article by NT medical officer, A.H. Humphry. Explaining the NHMRC policy guidelines, he described the Indigenous person as follows: 'his standard of hygiene is poor, he will not sleep apart, nor can he restrain his intense fondness for children. He does not understand the word "infectivity". ${ }^{45}$ This racial characterisation defined the Indigenous person as predisposed to unsanitary habits and the spreading of disease and, therefore, a potent public health risk. The focus on these perceived failings diverted attention away from the systemic problems of substandard housing and health services on many Indigenous settlements. ${ }^{46}$

Interestingly, the opposite tendencies, such as sleeping apart and lack of contact with children, were listed as criteria for discharge in the CTPH's general recommendations. It seems, therefore, that, although ostensibly applicable to patients of all races, these criteria were devised on the basis of a body of 'knowledge' about Indigenous people: that their behaviour was at the root of the leprosy problem, and that policy had to be directed to suppress or contain that behaviour.

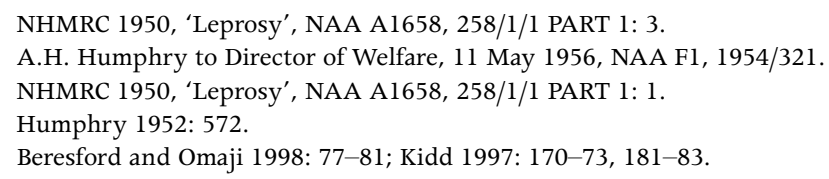


Under the mantle of medical expertise, this racial discourse provided a strong rationale for the continued support for leprosarium isolation by the NHMRC. Conveyed to state and territory health bureaucracies, it revealed a disregard for the new medical treatment where Indigenous patients were concerned. David Piers Thomas has discussed the reinforcement of preconceptions about Indigenous people in medical texts, arguing for its influence 'on the way doctors and other Australians think about Indigenous health' ${ }^{47}$ In the case of leprosy policy, the circulation of these ideas also potentially informed decisions about Indigenous health.

Piers Thomas also noted that, by the 1950s, doctors were explaining Indigenous health issues in terms of cultural background, rather than innate characteristics, as in earlier decades. ${ }^{48}$ These understandings were integral to social assimilation policies that, by promoting the re-education and resocialisation of Indigenous people, implicitly rejected 'fixed racial types' and, according to Haebich, 'rescued Aboriginal people from the stamp of race theories that branded them as inherently inferior' ${ }^{49}$ Historian John Murphy has shown that race, as a qualification for social services, also fell out of use and was replaced with mode of living, again linking this transition to government assimilation policy. ${ }^{50}$ The NHMRC recommendations, then, seem rather regressive for their time in their bold formulation of racially differentiated policies. Yet the fading of racial terminology in Indigenous policy documents did not necessarily indicate the meanings it represented had also disappeared. As Russell McGregor reminds us, by designating all Indigenous people in the Northern Territory as wards of the state, the Welfare Ordinance equated their race with Europeans in need of special care. ${ }^{51}$

\section{Australian leprosy policy implemented}

Until the late 1950s, state and territory health departments generally adhered to the recommendations of the NHMRC regarding the isolation and discharge of patients. But, in 1958, the Queensland Government began to relax its isolation policy for its European patients following recommendations by the medical superintendent of the Peel Island Leprosarium, M.H. Gabriel. After visiting several leprosaria overseas, Gabriel wanted to bring 'the treatment and control of Hansen's disease in QLD into line with current world trends' ${ }^{52}$ At a leprology

\footnotetext{
7 Piers Thomas 2004: 16.

8 Piers Thomas 2004: 90.

49 Raftery 2006: 164; Haebich 2008: 78.

50 Murphy 2013: 208-09.

51 McGregor 2011: 83.

52 QHMS 1959: 20. 'Hansen's disease' is an alternate name for leprosy.
} 
congress in Japan, his presentation had recommended abandoning strict isolation practices, particularly for 'white patients and other racial groups enjoying high standards of housing, sanitation and nutrition' ${ }^{53}$ The first step was the reduction of the number of negative bacteriological results required for the discharge from 12 to three. Initially, Cornelius O'Leary, Director of Native Affairs, suggested that 'a similar procedure should be followed in respect of patients at the Fantome Island lazaret', and listed 11 who qualified. ${ }^{54}$ On 'further consideration', however, health bureaucrats decided the modified requirements 'shall not be applied to coloured patients'. 55 This deeply disadvantaged Indigenous patients. If, after 11 months of consecutive negative readings, the twelfth one was positive, it meant at least one more year in the leprosarium.

The second step was the closure of the Peel Island leprosarium in 1959 and the transfer of the remaining patients to an isolation ward at South Brisbane Hospital. Thereafter, new European cases were admitted to this ward for short periods of treatment, and then released to 'home isolation' until their disease was arrested..$^{56}$ Similarly, from 1959, European cases in Western Australia began to be admitted to Perth's Sir Charles Gairdner Hospital, rather than the Wooroloo lazaret, usually staying for just three to six months. ${ }^{57}$ Wooroloo remained open a few more years as accommodation for some infirm patients.

Some of the people most affected by the implementation of NHMRC guidelines were Indigenous patients from remote areas. In 1956, Dr Humphry outlined the Northern Territory's policy to the Director of Welfare:

We are hesitant about discharging any patient to a locality that is remote or without a trained nurse or facilities for caring for the ex-patient. Such areas include cattle stations and such indefinine [sic] addresses as Mary River or Liverpool River. We do not discharge even the least infectious of cases to these areas as a rule. A few such patients who have had the disease very mildly and who we believe are completely cured are allowed to go. It would be unlikely that a patient with the infectious form of the disease would ever be permitted to leave for a remote area. ${ }^{58}$

This policy did not necessarily mean that Indigenous people who had responded well to the medication remained in isolation in this period. But, rather than going home, many were sent to live at missions or settlements where authorities trusted they could be supervised and given adequate living conditions

53 QHMS 1959: 20.

54 C. O'Leary to Superintendent, Palm Island Settlement, 15 September 1958, Queensland State Archives (hereafter QSA), series 4322, item ID714735.

55 Under Secretary to C. O'Leary, 31 December 1958, QSA, series 4322, item ID714735.

56 QHMS 1960: 5, 26.

57 Davidson 1978: 133.

58 A.H. Humphry to Director of Welfare, 11 May 1956, NAA F1, 1954/321. 
and care. There were many ramifications of this practice for former patients and their families, such as the prolonged separation from family and the social and emotional consequences for all involved. If the home area of Fantome Island patients was thought unsuitable, they were sent to Palm Island, sometimes forever. Robert Bismark of Cunnamulla remained there permanently because departmental officers, on a surprise inspection of his family's home, thought it was not clean enough. His family was not informed of his whereabouts and were heartbroken to learn of his fate, only after he had died. ${ }^{59}$

At least eight patients originally from the Mapoon mission in Cape York were also compelled to remain on Palm Island because the closest medical centre was too far away from their homes. One man had spent 14 years in the leprosarium and expressed his despair to a patient welfare organisation:

We all have no real home to go to ... All the ex-patients from Fantome Island including myself WE ALL NOT TAKING OUR TREATMENT HERE BECAUSE THE CONDITIONS IS VERY POOR ... Palm Island is no place for me unless they have classed me as a murderer because Palm Island is a punishment island. ${ }^{60}$

Subsequent inquiries by the Palm Island medical superintendent confirmed that this was a protest by the ex-patients, their intention being to induce a relapse of their disease and be returned to Fantome Island. The author of the letter, he noted, 'lives in a dirt-floored, corrugated iron structure containing a single stretcher ... its roof would undoubtedly leak' and survives on a vastly inadequate diet. ${ }^{61}$

As a result of these findings, the Queensland Director-General of Health, A. Fryberg, admitted that '[l]iving conditions at Palm Island are not conducive to the good health of native patients discharged from Fantome Island'. ${ }^{62}$ Yet 'good health' was ostensibly the reason for preventing Bismark and these other patients from going home. The health departments' objective of maintaining surveillance over the patients was evidently a more important factor. Still resident on Palm Island 30 years after his discharge from Fantome Island, Sandy Boyd from the Central Tablelands complained to an interviewer, 'you can't move here, you can't move there ... you move there, you go into jail. Over there you move anywhere you wanted to go. Trouble was I had to come here and get used to this' ${ }^{63}$ Other settlements may have been less restrictive and better resourced,

\footnotetext{
59 Hagan 2007.

60 Ex-patient to E. Hinton, Secretary, Relatives and Friends Association, 7 October 1954, QSA, series 505, item ID505017.

61 W.W. Wilson to Mr James, Secretary, Townsville Hospitals Board, 5 November 1954, QSA, series 505, item ID505017.

62 Fryberg to the Under Secretary, Department of Health and Home Affairs, 17 December 1954, QSA, series 505, item ID505017.

63 McHugh n.d., Interview with Sandy Boyd.
} 
but every case of the forced relocation of former leprosy patients re-enacted the historical motifs of Indigenous family fragmentation and oppressive state control. ${ }^{64}$

From about the middle of the 1950s, leprosy in Queensland showed signs of decline. Referring to the Indigenous population, Dr Fryberg predicted 'in a few years time Hansen's disease will be almost completely eliminated' ${ }^{65}$ Patient numbers at Fantome Island substantially dropped and by 1961, only 17 remained.$^{66}$ In 1965, the Queensland Health Department considered closing the leprosarium. Dr Gabriel supported the idea, arguing that if Indigenous patients were admitted to Brisbane Hospital with the European patients, they could receive superior rehabilitation services, and control of their own money. He argued, 'We would be able to say that there was absolutely no discrimination between white and coloured patients with Hansen's disease' ${ }^{67}$ But, it was eight years later when, with just six patients remaining, the leprosarium closed - by this time, in very poor shape. Buildings and equipment had been deteriorating for years with minimal repairs. ${ }^{68}$ Neither surgical and physiotherapeutic advances nor rehabilitative services had ever been introduced at the institution. Any required surgery had to be carried out on the mainland, with the inevitable difficulties and delays this entailed. Apart from occasional visits from a doctor 'who has little knowledge of about leprosy', treatment was limited to nursing care and informal occupational therapy by the resident nurses. ${ }^{69}$

In the Northern Territory, however, leprosy showed no signs of receding. Between 1950 and 1959, notifications more than trebled those of the previous decade: 459, including 447 Indigenous people. Between 1960 and 1969, there were 464 , including 441 Indigenous. ${ }^{70}$ This increase and spread to previously unaffected areas caused health authorities to strengthen their vigilance in identifying and detaining new cases. ${ }^{71}$ In 1953, Commonwealth DirectorGeneral of Health, A.J. Metcalfe, declared leprosy 'the worst medical problem in Northern Australia'.$^{72}$ Almost a decade later, NT Director of Health, Ian Byrne, ordered that any patient who had ever had a single positive bacterial test would be kept indefinitely in the leprosarium, thereby introducing tougher discharge criteria than those set by the NHMRC. ${ }^{73}$

64 Haebich 2000: 13; Broome 2010: 172.

65 QHMS 1956: 19.

66 QHMS 1962: 17.

67 M.H. Gabriel to Fryberg, 17 September 1965, QSA, series 505, item ID505023.

68 M. Malone to P. Killoran, Director, Aboriginal and Islander Affairs, 19 January 1967; D. Bowler to Medical Superintendent, QLD Hospitals Board, 18 January 1971, both in QSA, series 505, item ID505023.

69 Gabriel to Fryberg, 17 September 1965, QSA, series 505, item ID505023.

70 Lush et al. 1998: 711.

71 Humphry 1952; Davidson 1978: 109.

72 'Leprosy increases hold on natives', The West Australian, 18 February 1953: 1.

73 Byrne to J.C. Hargrave, Medical Officer, 22 August 1961, NAA A1658, 756/11/1 PART 2. 
Despite this stringency, the NT Health Department modified isolation in other respects, as Suzanne Parry has argued. The transfer of the leprosarium from distant and barren Channel Island to a new, well-equipped facility at East Arm on the mainland in 1955 brought patients much closer to the town centre of Darwin. This move facilitated greater involvement of clinical practitioners in patient care. Initiatives in the late 1950s to the middle 1960s, such as the establishment of a leprosy treatment centre in Arnhem Land, the deployment of survey nursing sisters, the training of Indigenous health workers and the introduction of long-acting sulphone injections all contributed to transferring treatment and surveillance from the leprosarium to patients' home areas. ${ }^{74}$

East Arm also led the way in introducing surgical and rehabilitative services in the same period. ${ }^{75}$ In a Commonwealth Health Department report in 1965, the leprosarium was promoted as a normal hospital where the 'patients are treated as ordinary patients', and the 'gates are left wide open'. ${ }^{76}$ Even so, under the Leprosy Ordinance 1954-1957 (NT), the Chief Medical Officer's consent was required for patients to leave the leprosarium, and for the public to come within 366 metres of its boundaries. ${ }^{77}$ The report explained that the leprosarium had changed its name to the 'East Arm Settlement', and emphasised its role as a surgical and rehabilitation facility. Accounting for the leprosarium's continued use as such, it said, 'it is better for patients to spend some time in a rehabilitation centre with other people who have the same problems' ${ }^{78}$ Whatever the practical benefits, this arrangement further segregated leprosy patients from society, and maintained separate health services for Indigenous people. In the 1970s, new case numbers dwindled, but only in 1980 the Leprosy Ordinance was repealed and leprosy was included with other diseases under the Notifiable Diseases Act 1981 (NT). The leprosarium closed the next year and outpatient services were transferred to Katherine.

In the north-west of Western Australia, Indigenous notifications, although falling in the 1950s and 1960s (227 and 200 respectively) compared with numbers in the 1940s (439), kept a steady flow of admissions to Derby Leprosarium in these decades. Many of the newly discovered cases came from an area bordering the Northern Territory and were part of the same outbreak causing concern to authorities in the Territory. Others resulted from a reactivation of the disease in the western Kimberley area that continued until the mid-1970s. Inpatient numbers at the leprosarium remained around 180 in the years 1962 to 1968.

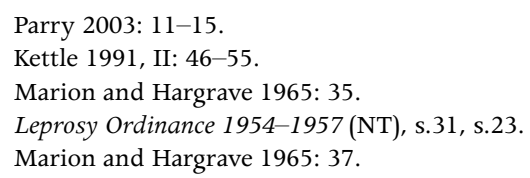


On average, these people stayed for 3.8 years. ${ }^{79}$ This was well beyond revised NHMRC recommendations of 1967, stipulating a minimum three to six months of isolation. ${ }^{80}$ The 1966 report of the Commissioner of Public Health stated that leprosy was declining in the Kimberley region and explained the constantly high numbers by the proportion of patients who were 'old and non-infectious', and 'as they get older can no longer cope with their disabilities and require institutional care. There is no institution for the aged in the Kimberleys unless they have had leprosy' ${ }^{81}$ Others were admitted for briefer periods for surgical repair of deformities. ${ }^{82}$ Thus, the leprosarium here, as in the Northern Territory, increasingly took on functions other than the quarantining of disease. These newer functions - surgery, rehabilitation and support of aged and disabled people - were clear indicators of the absence of those services outside the leprosarium.

Measures to enable outpatient care were not introduced in the region until approximately 10 years after their commencement in the Territory: remote area nursing care (mid-1960s), long-acting medication (mid-1970s), and Aboriginal health assistants (late 1970s). ${ }^{83}$ Until these latter improvements were introduced, the WA Health Department had not heeded the NHMRC's recommendations in 1967 and 1973 that 'every attempt should be made by the States and Territories to avoid unnecessary isolation of cases requiring treatment by providing proper facilities for the regular outpatient treatment and reassessment of as many cases as possible'. ${ }^{84}$

But by the late 1960s, treatment within the leprosarium was deficient. It had poor theatre equipment and other hospital facilities, could not provide patients with surgical boots and calipers, and had insufficient professional physiotherapy services, meaning that reconstructive surgery was either performed under difficult conditions or deferred ${ }^{85}$ Requests by staff to the government to improve facilities did not bear fruit until the mid-1970s, by which time patient numbers had fallen drastically. ${ }^{86}$

In 1985, the Health Department decided to close the Derby Leprosarium on 'economic and medical/social grounds' ${ }^{87}$ At last, officers of the department and doctors agreed that ' $[\mathrm{m}]$ odern management techniques ... negated the need

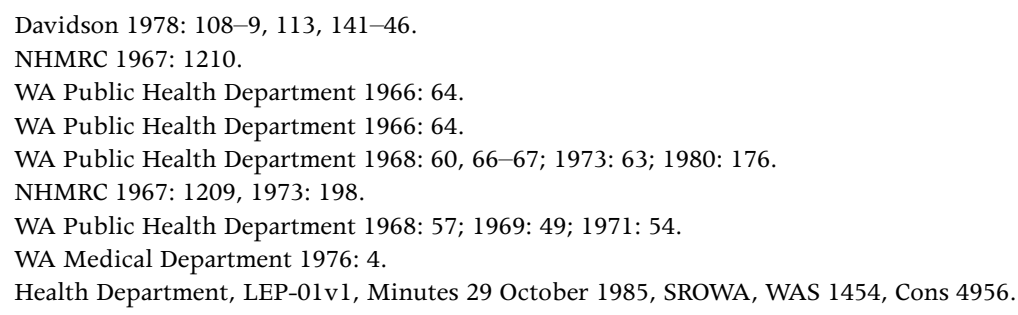


for the long term isolation and treatment of patients' ${ }^{88}$ Four elderly patients remaining when the leprosarium closed the next year were relocated to aged care facilities. Thereafter, new leprosy cases in the north were treated at Derby Regional Hospital. Inexplicably, the Western Australian Government did not repeal s.273 of the Health Act; it remains in the current version of the Act with the pejorative title, 'Treatment and custody of lepers' ${ }^{89}$

\section{Disability welfare services}

This section examines some Australian Government welfare services in the 1950s and 1960s for people with disabilities and the extent to which they were available to leprosy patients. A government report showed that between 1951 and 1960, 48 per cent of Northern Territory patients had a disability in the lower limbs, and 57 per cent had upper limb disabilities. The figures for the following decade - 28 per cent and 37 per cent - were improved due to the benefits of drug therapy, but are still significant. ${ }^{90}$ In order to attain some degree of independence or physical functionality, a range of rehabilitative and other services were desirable; for example, surgical repair for deformities, prostheses for amputations, occupational therapy, and physiotherapy. Physical dysfunction severely impacted on the welfare of the individual and his/her family, whether survival depended on traditional hunting and fishing, or on wage-earning labour. Opportunities for the latter were further curtailed by the persistent social stigma accompanying leprosy, so financial assistance was essential for patients and their families, as were psychological support services. Without such measures, it was difficult for some patients to survive and they comprised 'the crippled or other cases' deemed by the NHMRC to remain in the leprosy institution.

Financial support was hard to obtain for Indigenous leprosy sufferers, forcing many to remain dependent on the rations of poorly resourced settlements and missions, or on the leprosarium itself. Whether inpatients or discharged cases, most received no financial aid from the government for themselves or their families, apart from the low wage some earned as leprosarium workers. European and some mixed-descent patients who shared the same circumstances were eligible for the Commonwealth invalid, aged and service pensions, as well as a dependants' allowance from the Queensland Government if resident in that state. The 1959 amendments to the Commonwealth Social Services Act, extending pensions to all but 'primitive' Indigenous people, did little to relieve

88 Health Department, LEP-01v1, Minutes 29 October 1985, SROWA, WAS 1454, Cons 4956

89 Health Act 1911 (WA) as at 6 September 2014, s.273.

90 Planning Division, Commonwealth Department of Health 1976: 3. 
this disparity. The superintendents of settlements, missions and leprosaria withheld more than 25 per cent of residents' pensions under the 'institutional scheme' and, in addition, leprosarium patients had an additional 65 per cent retained by health departments to cover their treatment and maintenance. ${ }^{91}$ European patients had never been levied for their maintenance, nor were they subjected to the indignity and financial disadvantage of the 'pocket money' system. ${ }^{92}$

Neither European nor Indigenous leprosy patients received an allowance equivalent to the federal Tuberculosis Allowance, which had been in effect since 1948. Throughout the 1950s, the NHMRC's CTPH had urged the Commonwealth Government to introduce this benefit, arguing that 'at no time has the sufferer from tuberculosis been compelled to endure the financial hardships and social disabilities imposed upon the leper by the drastic Australian methods of prophylaxis against leprosy'.$^{93}$ The allowance, the CTPH maintained, would provide the means for discharged patients to look after themselves and help to prevent relapse of their disease. The Tuberculosis Allowance excluded Indigenous people who were under the control of state and territory welfare legislation, so any corresponding leprosy allowance may have had the same restrictions. This payment was not as much a welfare benefit as a cash inducement to sufferers to give up their jobs and submit themselves for treatment. The government had no reason to offer inducements to leprosy patients, as they were compelled to present for treatment.

In 1941, the Vocational Training for Invalid Pensioners scheme was established to provide 'suitable treatment and vocational training at the Commonwealth's expense with a view to enabling them to learn some suitable craft or occupation whereby they may eventually become self-supporting' ${ }^{94}$ The participants were also given financial support and, if required, artificial limb replacements, surgical aids and appliances, free of charge. In 1953, the Department of Social Services turned down requests by the Relatives and Friends Association, a leprosy patient welfare organisation, for the inclusion of discharged Queensland patients in the scheme. ${ }^{95}$ Following a departmental inquiry, the Director, Clive Burdeu, was convinced that 'the reestablishment of those who

\footnotetext{
91 Byrne to W.F. Refshauge, Commonwealth Director-General of Health, 13 October 1961, NAA A1658, 756/11/1 PART 2; H.W. Smetherham, Acting Director, WA Department of Social Services to DirectorGeneral, Social Services, 5 October 1964, NAA A886, C261; on the 'institutional' scheme as applied generally to Indigenous pensioners, see Kidd 2006: 96-97.

92 Mother Marion, Matron, East Arm Leprosarium to Refshauge, 18 November 1963, NAA A1658, 756/11/1 PART 2.

93 NHMRC 1950, 'Leprosy', NAA A1658, 258/1/1 PART 1: 5.

94 Commonwealth Bureau of Census and Statistics 1951: 325.

95 F.H. Rowe, Director-General of the Department of Social Services to Clive Burdeu, Director of Social Services, 11 August 1953, NAA A886, C174.
} 
have suffered is almost hopeless'.${ }^{96}$ Summarising his findings to the DirectorGeneral, F.H. Rowe, he argued that employers would not accept former patients in the workforce due to the 'ignorance and prejudice in the community', but that 'the problem is not a big one because the number of whites suffering from Hansen's disease is small' ${ }^{97}$ Twenty-three European patients at Peel Island had been under consideration, of which only four to five were thought capable of rehabilitation. ${ }^{98}$

The Relatives and Friends Association repeated its request in 1956, by which time the scheme was known as the Commonwealth Rehabilitation Service. This time the department revised its original policy, seeking, in Rowe's words, 'conformity with the modern approach to the problem' ${ }^{99}$ Newly inspired by advice from the Principal Medical Officer, Rowe was mindful of the government's responsibility to discountenance public fear of leprosy. He therefore permitted former sufferers to enter the rehabilitation program which, he assured the Minister for Social Services, was 'of considerable value psychologically as well as physically'. Again, the policy did not include Indigenous patients, for he remarked that eligible candidates would probably consist only of a few cases, all from Queensland. ${ }^{100}$

In government correspondence, there was no discussion about the possibility of Indigenous patients accessing this scheme - perhaps because nobody approached the responsible department on their behalf. Few patients would have been in a position to make the inquiry themselves, let alone known of the scheme. Had Indigenous cases been tested against eligibility criteria of the scheme, they should have complied. The relevant legislation did not stipulate any racial grounds for exclusion from the scheme. Applicants were required to be in receipt of either the invalid pension or the TB allowance. This certainly limited, but did not entirely exclude, Indigenous leprosy patients from eligibility, as a few were pensioners by 1953. There would be many more after the removal of the last racial restrictions from social security provisions in 1959. Another requirement was determination by 'the Director-General there are reasonable prospects of [the candidate] engaging in a suitable vocation within a period of two years after commencement of training or treatment ${ }^{\prime} .{ }^{101}$ As highlighted above, officers were prepared to apply a wide interpretation of this clause to European leprosy patients. Their actions in that respect were proof that, although the

\footnotetext{
96 Burdeu to Rowe, 29 July 1953, NAA A886, C174.

97 Burdeu to Rowe, 29 July 1953, NAA A886, C174.

98 G.A. McLean, Rehabilitation of Leprosy Patients', 19 June 1953, NAA A886, C174.

99 Rowe to W. McMahon, Minister for Social Services, 4 May 1956, NAA A886, C174.

100 Rowe to W. McMahon, Minister for Social Services, 4 May 1956, NAA A886, C174.

101 Social Services Consolidation Act (No. 2) No. 69 of 1948 (Cth), s.135a.
} 
Commonwealth Rehabilitation Service was essentially a program to promote full employment, by the mid-1950s, officers were beginning to offer its services on the basis of direct health benefits to applicants.

\section{Conclusion}

Until the 1980s, the compulsory and long-term isolation of Indigenous people in leprosaria remained a feature of Australian leprosy control policy. Groundbreaking advances in therapy from the late 1940s did not curtail this practice, except for European patients after 1959. The new drugs did lead to vast improvements in patients' health and, to a limited extent, the modification of isolation practices. This study has shown that in the postwar period and beyond, this two-speed leprosy policy was shaped by two factors. The first was the characterisation of Indigenous people as intrinsically irresponsible with their health and, therefore, risks to public health, as promulgated in medical and bureaucratic discourse. Second, structural inequities in government health and welfare services prevented many Indigenous people, particularly those with disabilities, from attaining an adequate standard of living or undergoing rehabilitation. Rather than address these shortfalls, governments continued to operate the leprosaria so that treatment could proceed under medical surveillance. In some cases, the leprosaria provided rehabilitative and surgical care. Thus health services for Indigenous people continued to be supplied in a separate setting to that of European people, a setting that bore a stigma because it functioned as a detention centre for contagious patients and was off-limits to the public.

The perpetuation of the leprosarium isolation policy for Indigenous people and their disqualification from health and welfare services after World War Two occurred despite shifts in Indigenous affairs policies towards social assimilation in the 1950s and 1960s, and in spite of the extension of Commonwealth welfare benefits to a wider range of disadvantaged Australians in this period. The welfare apartheid operated insidiously, only visible by examining what DeMaria has called 'the private side of public welfare'; in the instances discussed above, the pension money given by one government to be snatched back by another; government resistance to supporting Australians with a particular disease where the burden of that disease fell mostly on Indigenous people; and, the failure of the system to reach out to remote Indigenous people with disabilities. ${ }^{102}$ 


\section{References}

\section{Archival sources}

\section{National Archives of Australia (NAA)}

NAA Canberra, series A886, item C174 Fantome Island Leprosarium - Pension claims by inmates

NAA Canberra, series A886, item C261 Leprosarium at East Arm, Darwin (Formerly of Channel Island) - Entitlement of inmates to pensions and allowances

NAA Canberra, series A1658, item 258/1/1 PART 1 Diseases - Leprosy General - General

NAA Canberra, series A1658, item 756/11/1 PART 2 Northern Territory - East Arm settlement - General

NAA Canberra, series A1928, item 715/38/1 SECTION 3 Northern Territory Leper Stations Channel Island - Darwin Section 3

NAA Canberra, series F1, item 1954/321 Leper Matters - General

\section{Queensland State Archives (QSA)}

QSA, series 505, item ID505017 Correspondence, Aboriginal and Torres Strait Islander; Administration - Palm Island - Fantome Island - Leprosarium Patient Welfare

QSA, series 505, item ID505023 Correspondence, Aboriginal and Torres Strait Islander; Administration - Palm Island - Control Fantome Island Lazaret

QSA, series 4322, item ID714735 Correspondence, Aboriginal and Torres Strait Islander; Fantome Island - General

\section{National Library of Australia}

National Library of Australia, Siobhan McHugh Collection of Australian Social History 198 - 'Interview with Sandy Boyd'

\section{State Records Office of Western Australia}

State Records Office of Western Australia, WAS 1454, Cons 4956 


\section{Government publications}

Commonwealth Bureau of Census and Statistics 1951, Official Year Book of the Commonwealth of Australia No. 38-1951, cat. no. 1301.0, CBCS, Canberra.

1953, Official Year Book of the Commonwealth of Australia No. 39-1953, cat. no. 1301.0, CBCS, Canberra.

Commonwealth Department of Health 1957, Health: Journal of the Commonwealth Department of Health, March, 1957, The Department, Canberra.

Marion, Rev. Mother and J.C. Hargrave 1965, 'New approach to an old Problem', Australian Territories (Canberra: Department of External Territories), 5(6): 31-38.

NHMRC (National Health and Medical Research Council) 1958, 'Leprosy and its Management', in Commonwealth Department of Health, Health: Journal of the Commonwealth Department of Health, March, 1958, The Department, Canberra: 20-26.

1967, 'Leprosy Control in Australia' (excerpt from the report of the 65th Session of the NHMRC), Medical Journal of Australia 27(2): 1209-11.

1973, 'Appendix XXXVII: Leprosy Control in Australia', National Health and Medical Research Council: Report of the Seventy-seventh Session, Canberra, Australian Government Printing Service, Canberra, 197-201.

Planning Division, Commonwealth Department of Health 1976, NT Medical Service Leprosy Plan, Department of Health (NT Division), Darwin.

QLD Health and Medical Services Branch, Annual Report on the Health and Medical Services of the State of Queensland 1945-1983, The State, Brisbane.

Western Australia, Public Health Department, Report of the Commissioner of Public Health 1948-1983, Department of Public Health, Perth.

Western Australia, Medical Department 1976, Report of the Medical Department of Western Australia 1976, Government Printer, Perth.

\section{Secondary sources}

Anon. 1948, 'Fifth International Leprosy Congress', International Journal of Leprosy 16(2): 187-244.

Banerjee, Ashis 2006, 'Paul Brand (1914-2003): The surgeon who recognised the importance of pain', Journal of Medical Biography 14(3): 137. 
Bashford, Alison 2004, Imperial Hygiene: A Critical History of Colonialism, Nationalism and Public Health, Palgrave, Sydney.

Beresford, Quentin and Paul Omaji 1998, Our State of Mind: Racial Planning and the Stolen Generations, Fremantle Arts Centre Press, Fremantle, WA.

Broome, Richard 2010, Aboriginal Australians: A History since 1788, 4th edn, Allen \& Unwin, NSW.

Cumpston, J.H.L. 1989 [1928], Health and Disease in Australia: A History, introduced and edited by M.J. Lewis, Australian Government Printing Service, Canberra.

Davidson, W.S. 1978, Havens of Refuge: A History of Leprosy in Western Australia, University of Western Australia Press for the Public Health Department, Nedlands.

DeMaria, William 1986, “'White welfare: Black entitlement": The social security access controversy, 1939-59', Aboriginal History 10(1): 25-39.

Faget, G.H. and Paul T. Erickson 1948, 'Chemotherapy of Leprosy', Journal of the American Medical Association 136(7): 451-57.

Gilroy, John, Michelle Donelly, Susan Colmar and Trevor Parmenter 2013, 'Conceptual framework for policy and research development with Indigenous people with disabilities', Australian Aboriginal Studies, no. 2: 42-58.

Gussow, Zachary 1989, Leprosy, Racism and Public Health, Westview Press, Boulder, San Francisco and London.

Haebich, Anna 2000, Broken Circles: Fragmenting Indigenous Families 1800-2000, Fremantle Arts Centre Press, Fremantle.

2008, Spinning the Dream: Assimilation in Australia 1950-1970, Fremantle Press, North Fremantle.

2012, 'Aboriginal assimilation and Nyungar health 1948-72', Health and History 14(2): 140-61.

Hagan, Stephen 2007, 'A testimony of injustice', On Line Opinion, www.online opinion.com.au/view.asp? article $=5425 \&$ page $=2$ (accessed 8 October 2015).

Hollinsworth, David 2013, 'Decolonizing Indigenous disability in Australia', Disability and Society 28(5): 601-15.

Humphry, A.H. 1952, 'Leprosy among full-blooded Aborigines of the Northern Territory', Medical Journal of Australia 17(1): 570-73. 
Kettle, Ellen 1991, Health Services in the Northern Territory: A History 1824-1970, 2 vols, North Australia Research Unit, Darwin.

Kidd, Rosalind 1997, The Way We Civilise: Aboriginal Affairs - The Untold Story, University of Queensland Press, St Lucia.

2006, Trustees on Trial: Recovering the Stolen Wages, Aboriginal Studies Press, Canberra.

Leung, Angela Ki Che 2009, Leprosy in China: A History, Columbia University Press, New York.

Lush, Douglas, John C. Hargrave and Angela Merianos 1998, 'Leprosy control in the Northern Territory', Australian and New Zealand Journal of Public Health 22(6): 709-13.

Macintyre, Stuart 1985, Winners and Losers: The Pursuit of Social Justice in Australian Welfare History, Allen and Unwin, Sydney.

McGregor, Russell 2011, Indifferent Inclusion: Aboriginal People and the Australian Nation, Aboriginal Studies Press, Canberra.

Meekosha, Helen 2011, 'Decolonising disability: Thinking and acting globally', Disability and Society 26(6): 667-82.

Moran, Michelle T. 2007, Colonizing Leprosy: Imperialism and the Politics of Public Health in the United States, University of North Carolina Press, Chapel Hill.

Murphy, John 2013, 'Conditional inclusion: Aborigines and welfare rights in Australia, 1900-47', Australian Historical Studies 44(2): 206-26.

Parry, Suzanne 2003, "'Of vital importance to the community": The control of leprosy in the Northern Territory', Health and History 5(1): 1-21.

Piers Thomas, David 2004, Reading Doctors' Writing: Race, Politics and Power in Indigenous Health Research, 1970-1969, Aboriginal Studies Press, Canberra.

Raftery, Judith 2006, Not Part of the Public: Non-Indigenous Policies and Practices and the Health of Indigenous South Australians 1836-1973, Wakefield Press, Kent Town, SA.

Sato, Hajime and Janet E. Frantz 2005, 'Termination of the leprosy isolation policy in the US and Japan: Science, policy changes, and the garbage can model', BMC International Health and Human Rights 5(3). doi: 10.1186/1472698X-5-3. 
Saunders, Suzanne 1990, 'Isolation: The development of leprosy prophylaxis in Australia', Aboriginal History 14(2): 168-81.

Sloan, N.R., E.K. Chung-Hoon, M.E. Godfrey-Horan and G.H. Hedgcock 1950, 'Sulphone therapy in leprosy: A three-year study', International Journal of Leprosy 18(1): 1-9.

Waters, W.J. 1976, 'Australian Labor's full employment program objective, 1942-5', in Social Policy in Australia: Some Perspectives 1901-1975, Jill Roe (ed.), Cassell, Australia, Stanmore.

WHO (World Health Organization) 1953, ‘Expert Committee on Leprosy First Report', WHO Technical Report Series no. 71, WHO, Geneva.

1960, 'Expert Committee on Leprosy - Second Report', WHO Technical Report Series no. 189, WHO, Geneva.

1966, 'Expert Committee on Leprosy - Third Report', WHO Technical Report Series no. 319, WHO, Geneva. 
This text is taken from Aboriginal History, Volume 40, 2016, edited by Liz Conor, published 2016 by ANU Press,

The Australian National University, Canberra, Australia. 